\title{
Reluctant Innovators? Inter-Organizational Conflict and the U.S.A.'s Route to Becoming a Drone Power
}

\author{
Marc R. DeVore \\ School of International Relations, Arts Building, The Scores, St Andrews, UK \\ mrd7@st-andrews.ac.uk
}

\begin{abstract}
Few military innovations have marked the late $-20^{\text {th }}$ and early- $21^{\text {st }}$ centuries more than unmanned aerial vehicles, which are better known as drones. Drones' current preeminence leads many today to assume that their development was straightforward; teleologically determined by technological advances. The empirical record, however, belies such assumptions and is rather filled with vicissitudes. To assess this process, I examine the United States' development of drones up until they achieved prominence after the September 2001 terrorist attacks. To preview my conclusions, the case of drones highlights the central role of inter-organization competition in military innovation. The Air Force's and Naval aviation's pilot-dominated hierarchies never prioritized drones of their own accord because of their preferences for manned aircraft. Political leaders, meanwhile, lacked the expertise to judge what drone technologies could achieve and therefore could not compel the military to embrace them. It was, within this context, competition from organizations - the CIA, the Navy's surface warfare community and the Army - that did not hold the preservation of manned aviation as a core belief that obliged reluctant aviators to embrace drones. My study's key original finding is that inter-agency competition impels military organizations to embrace technologies that they would otherwise reject. Warfare's evolution means that non-military bodies - intelligence agencies, interior ministries and paramilitary police forces - develop capabilities that render them rivals of traditional military services in specific domains. Since such organizations feature different career trajectories and hierarchical structures from military services, they can prove more agile at adopting new technologies.
\end{abstract}

Keywords: military innovation, drones, unmanned aerial vehicles, UAV, unmanned combat air vehicle, UCAV, Central Intelligence Agency, CIA, Air Force, inter-service competition, inter-organizational competition, Predator, Lightning Bug, Vietnam War, War on Terrorism

\section{Introduction}

Few military innovations have marked the late $-20^{\text {th }}$ and early- $21^{\text {st }}$ centuries more than unmanned aerial vehicles, which are better known as drones. Long considered a marginal military tool, drones have first become central to great powers' visions of future warfare. 
Predator and Reaper drones have spearheaded the United States' campaign to kill insurgents and terrorist leaders. American military planners, meanwhile, envisage drones replacing manned aircraft and satellites for such missions as reconnaissance from the stratosphere, communications relays and mid-air refueling. All major powers even now are experimenting with stealthy drones designed from air-to-air combat and attacking heavily defended targets. Many experts anticipate that drones will soon supplant manned combat aircraft in the foreseeable future given the meteoric development of artificial intelligence.

Drones' current preeminence leads many today to assume that their development was straightforward; teleologically determined by technological advances. The empirical record, however, belies such assumptions and is rather filled with vicissitudes. The United States Air Force, which is today the world's premier drone user, actually developed a sophisticated drone arsenal in the 1960s, which it used to collect intelligence on and conduct airstrikes against North Vietnam's most heavily defended targets.

After the Vietnam War, however, the Air Force disbanded and scrapped its drone force. A decade then elapsed before the Navy reintroduced drones into front-line American service, by purchasing inexpensive Israeli drones to operate from antiquated American battleships. After the Navy brought back drones in the 1980s, it was the CIA that developed the Predator drone's forebearer - the Gnat 750 - in the 1990s. Only at the end of this process, in the late1990s, did the Air Force once again embrace drones, thereby setting the stage for the dramatic growth in their usage during the so-called War on Terror.

Drones' convoluted evolution raises questions about the military innovation process. Why, for example, did the Air Force marginalize drones even after their value had been proven in combat? The corollary to this question is why did the Air Force's leadership warmly embrace drones during certain periods, while it rejected them during others? To answer these questions, I assess the United States' development of drones up until they achieved prominence after the September 2001 terrorist attacks.

To preview my conclusions, the case of drones highlights the central role of interorganization competition in military innovation. The Air Force's and Naval aviation's pilotdominated hierarchies never prioritized drones of their own accord because of their preferences for manned aircraft. Political leaders, meanwhile, lacked the expertise to judge what drone technologies could achieve and therefore could not compel the military to embrace them. It was, within this context, competition from organizations - the CIA, the Navy's surface warfare community and the Army - that did not hold the preservation of manned aviation as a core belief that obliged reluctant aviators to embrace drones. 
My study's key original finding is that inter-agency competition impels military organizations to embrace technologies that they would otherwise reject. Warfare's evolution means that non-military bodies - intelligence agencies, interior ministries and paramilitary police forces - develop capabilities that render them rivals of traditional military services in specific domains. Since such organizations feature different career trajectories and hierarchical structures from military services, they can prove more agile at adopting new technologies.

\section{Agents of innovation}

The over-riding importance of new ways of waging war - armoured divisions, aircraft carriers and radar-directed air defence - stirred many military professionals to regard the timely adoption of new technologies as crucial to success following the Second World War. French General Charles Ailleret best summarized this new reality when he wrote, 'the greatest change in the art of war is that a military [today] is bound to be crushed if it does not apply itself intensely to ensuring that its weapons are both "up to date" and adapted to its future missions.' 1 Nuclear weapons' and long-range missiles' impact on the public consciousness in the years following the Second World War then drove scholars to first systematically examine how states innovate militarily. Despite the ensuing decades of academic inquiry, experts still disagree as to how military innovation occurs.

Political leaders constitute the first category of actor whom certain scholars argue are central to innovation. According to Barry Posen, political leaders force military organizations to embrace new technologies, tactics and modes of organization. ${ }^{2}$ Military organizations, within this context, are conceptualized as parochial organizations whose ability to embrace new means of making war is hindered by their bureaucratic politics. Innovation, consequently, occurs when the international environment alarms politicians to such an extent that they force their militaries to embrace innovations essential to national security. Political leaders, according to Posen, accomplish this by partnering with "mavericks" within the military, whose ideas are otherwise ignored by higher ranking officers. ${ }^{3}$

${ }^{1}$ Charles Ailleret, L'art de la guerre et la technique (Limoges: Charles-Lavauselle, 1950), 23.

${ }^{2}$ Barry Posen, The Sources of Military Doctrine: France, Britain and Germany Between the World Wars (Ithaca: Cornell UP, 1984).

${ }^{3}$ Ibid, 220-244. 
Although Posen offers a particular vision of how political leaders promote innovation, other scholars support his general message. Kimberley Marten Zisk and Sten Rynning, for example, detail how leaders can build-up and then draw upon think tanks filled with civilian national security experts to develop and impose new military doctrines. ${ }^{4}$ Studying the Soviet case, Matthew Evangelista goes further, arguing that Soviet institutions were so hierarchical that only political leaders' intervention could generate meaningful change, such as when Premier Nikita Khrushchev reallocated resources from conventional platforms to missiles. ${ }^{5}$

An alternative school of thought argues that military organizations develop innovations endogenously. Stephen Rosen led the way in this regard, arguing that political leaders lack the specialist knowledge needed to promote innovations and that military organizations are not as conservative as Posen asserted. ${ }^{6}$ Military officers, according to Rosen, possess more comprehensive understandings of tactical trends and enemy capabilities than their political superiors. Innovation therefore occurs when top-level commanders recognize emerging trends in war-making. Military leaders, within this context, promote junior officers in new specialities and thereby lay the basis for gradual, but critical innovations.

Recent scholarship on the Second World War supports this re-interpretation of classic military innovations. New studies of Germany's blitzkrieg, ${ }^{7}$ Japanese aircraft carriers ${ }^{8}$ and American naval preparations for the Pacific $\mathrm{War}^{9}$ all highlighted the role of highly functioning, yet staid military bureaucracies in generating revolutionary innovations. Moreover, historians first and then political scientists recognized military organizations' ability to generate

${ }^{4}$ Kimberley Zisk, Engaging the Enemy: Organization Theory and Soviet Military Innovation, 1955-1991 (Princeton: Princeton UP, 1993); and Sten Rynning, Changing Military Doctrine: Presidents and Military Power in Fifth Republic France, 1958-2000 (Boulder: Westview, 2001).

${ }^{5}$ Matthew Evangelista, Innovation and the Arms Race: How the United States and the Soviet Union Develop New Military Technologies (Ithaca: Cornell UP, 1988).

${ }^{6}$ Stephen Rosen, Winning the Next War: Innovation and the Modern Military (Ithaca: Cornell UP, 1991).

${ }^{7}$ James Corum, The Roots of Blitzkrieg: Hans Von Seeckt and German Military Reform (Lawrence: Kansas UP, 1992).

${ }^{8}$ David Evans and Mark Peattie. Kaigun: Strategy, Tactics, and Technology in the Imperial Japanese Navy, 1887-1941 (Annapolis: Naval Institute, 1997).

${ }^{9}$ John Kuehn, Agents of Innovation: The General Board and the Design of the Fleet that Defeated the Japanese Navy (Annapolis: Naval Institute, 2008). 
innovations from the bottom up. Battlefield experience, whether in World War I trenches ${ }^{10}$ or Normandy's hedgerows,${ }^{11}$ drove military organizations to rapidly re-evaluate and improve how they waged war.

Not all scholars, however, proved so sanguine as to military bureaucracies' aptitude to reform themselves. Many scholars, indeed, view armed forces' ingrained platform communities as an obstacle to their embracing radical innovations. Edward Katzenbach's seminal study of the survival of the horse cavalry units until the mid- $20^{\text {th }}$ century forcefully made this point. ${ }^{12}$ According to Katzenbach, the fact that top cavalry officers had spent their entire careers mastering a particular form of warfare shaped burdened them with motivated biases when it came to evaluating their branch's future. According to Katzenbach, 'Romanticism, while perhaps stultifying realistic thought, gives a man that belief in the value of the system he is operating that is so necessary to his willingness to use it in battle....But faith [in a weapons system or tactic] breeds distrust of change. ${ }^{13}$

Building on Katzenbach's insight, Carl Builder argues that military services will embrace only those new weapons that enhance their dominant platform communities, while rejecting those that do not. ${ }^{14}$ Elizabeth Kier and David Johnson, in related arguments, postulate that military services' distinctive organizational cultures often prevent them from adopting the optimal structures and tactics. ${ }^{15}$ Other scholars, meanwhile, argued that armed services' selfconceptions can lead them to reject superior ways of waging war altogether. ${ }^{16}$

${ }^{10}$ Bruce Gundmundsson, Stormtroop Tactics: Innovation in the German Army, 1914 1918 (Westport, CT: Praeger 1995).

${ }^{11}$ Michael Doubler, Closing with the Enemy: How GIs Fought the War in Europe, 1944-1945 (Lawrence: Kansas UP, 1994).

12 Edward L. Katzenbach Jr., "The Horse Cavalry in the Twentieth Century," Public Policy 7 (1958): 120-49.

${ }^{13}$ Ibid, 149.

${ }^{14}$ Carl H. Builder, The Masks of War: American Military Styles in Strategy and Analysis (Baltimore, MD: Johns Hopkins University Press, 1989).

${ }^{15}$ Elizabeth Kier, Imagining War: French and British Military Doctrine Between the Wars (Princeton: Princeton UP, 1997); and David Johnson, Fast Tanks and Heavy Bombers: Innovation in the U.S. Army, 1917-1945 (Ithaca: Cornell, 1998).

${ }^{16}$ Leonard Humphreys, The Way of the Heavenly Sword: The Japanese Army in the 1920's (Palo Alto: Stanford UP, 1995); and Craig Cameron, American Samurai: Myth, 
Examined holistically, neither of the two models detailed above - of civilian-led and military-led innovation - is wholly convincing. While political leaders, indeed, have incentives to force their armed forces to adopt the most innovative and effective ways of waging war, they generally lack the expertise and managerial leverage to do so. Robert Coulam's study of American political leaders' unsuccessful efforts to shape combat Cold War aircraft projects bolsters this finding. ${ }^{17}$ Military bureaucracies, however, after often loath to embrace radical changes that would threaten their dominant platform communities. If political leaders lack the wherewithal to promote innovations and military commanders will hesitate to enact reforms that could undermine their cherished combat arms, then the question remains as to how military innovation occurs?

\section{Inter-organizational competition}

One mechanism whereby otherwise reluctant military organizations can be prompted to adopt radical innovations lies in inter-organizational conflict. Armed services, indeed, regularly compete with one another and with other government agency for their roles and missions. Achieving primary responsibility for fulfilling key missions, within this context, increases the resources that an organization will command and enhances its prestige at the national level. This incentive to secure leadership over important national security missions, and the accompanying fear of losing responsibility to a rival organization, provides a powerful incentive for armed services to adopt even those military innovations they would otherwise eschew. Two varieties of inter-organizational competition - inter-service and inter-agency can produce such an impetus to innovation.

Policymakers have traditionally regarded inter-service rivalry as an impediment to the sound management of a state's defence. Such rivalries are often viewed as needlessly parochial, diverting resources from the efficient accomplishment of objectives. Often referenced cases supported this point-of-view. President Franklin Roosevelt, for example, divided the Pacific Ocean into two operational theatres during World War II to appease the United States' Army and Navy, which each wanted to control the war against Japan. Japan's Army and Navy, for their part, wasted resources duplicating one another's capabilities, with the Army acquiring

Imagination, and the Conduct of Battle in the First Marine Division, 1941-1951 (Cambridge: Cambridge UP, 1994).

17 Robert Coulam, Illusions of Choice: The F-111 and the Problem of Weapons Acquisition Reform (Princeton: Princeton UP, 1977). 
aircraft carriers and the Navy possessing its own infantry. Michael Armacost's seminal study of Cold War missile programs, however, offers an alternative view of inter-service rivalry. ${ }^{18}$

Armacost's examination of the United States Army's and Air Force's ballistic missile programs led him to conclude that inter-service competition drives innovation. The Air Force, within this context, accorded a low priority to ballistic missiles until the Army launched its competing Jupiter missile program. Rivalry between two design teams, beholden to separate services, thereafter spurred technical advances that improved both missile programs, such as when the Army's superior heat-shielding for warheads was adopted by both services. Armacost's finding - that inter-service competition fuels innovation - was unambiguous.

While Armacost induced the relationship between inter-service competition and innovation from his study, it fell to Owen Coté to theorize the relationship. ${ }^{19}$ According to Coté, inter-service rivalry is particularly prone to foster innovation because it forces military services to embrace even those changes that threaten existing platform communities because doing so will be less prejudicial than allowing a rival service to dominate the new capability. In Coté's own words, inter-service competition creates conditions where 'a service becomes interested in developing a new combat arms even when it comes at the expense of existing ones, in order to fend off the claims of a branch of a rival service seeking a monopoly on the new instrument of war.' 20

Ultimately, Coté argues that such inter-service competition indirectly empowers political leaders. Such is the case because 'the central authority responsible for the adjudication of interservice arguments and negotiations over doctrine is ultimately a civilian one. ${ }^{21}$ In other words, inter-service competition forces military services to appeal to political leaders, couching their rival arguments in terms comprehensible to civilian policymakers and allowing these later to decide which services' claims to support.

While Armacost and Coté persuasively argue that inter-service competition promotes military innovation, they neglect the possibility that competition between military services and

${ }^{18}$ Michael Armacost, The Politics of Weapons Innovation: The Thor-Jupiter Controversy (New York: Columbia UP, 1969).

${ }^{19}$ Owen Coté, The Politics of Innovative Military Doctrine: The U.S. Navy and Fleet Ballistic Missiles (Ph.D. Dissertation, Massachusetts Institute of Technology).

${ }^{20}$ Ibid, 79.

${ }^{21}$ Ibid, 77. 
other governmental agencies can drive military innovation as well. Powerful reasons exist, however, for anticipating that inter-service competition can play an analogous role to interservice rivalry in this regard. The evolving security challenge facing states, indeed, has led non-military agencies to acquire capabilities that rival those of armed services in specific domains. Intelligence agencies, for example, can develop reconnaissance aircraft, surveillance satellites and paramilitary units. Coastguards, meanwhile, procure fleets of patrol vessels, helicopters and surveillance aircraft that can enforce maritime claims more efficiently than navies. Law enforcement agencies, likewise often develop counter-terrorist and riot control capabilities that can efficaciously operate abroad.

Since such agencies can technically compete with armed services for specific roles and missions, they can also logically spur the latter to innovate. Such is particularly the case because civilian agencies possess comparative advantages when it comes to innovating. A considerable management literature contends that small and agile corporations often outinnovate larger industrial behemoths. Since civilian agencies - intelligence, coastguards and law enforcement - generally possess flatter organizational structures and more flexible personnel policies than armed services, they should demonstrate analogous advantages when it comes to embracing new ways of operating.

Considerable anecdotal evidence suggests that such inter-agency competition can drive military innovation. It was the CIA's Science and Technology Directorate, for example, that compelled the Air Force to embrace stealthy aircraft and reconnaissance satellites. ${ }^{22}$ In both cases, the CIA's more flexible procurement procedures and greater solicitude for acquiring high quality imagery led it to invest in risky technologies in which the Air Force had demonstrated little interest. The Air Force, by way of contrast, viewed reconnaissance as a lowpriority mission and uncreatively modified conventional combat aircraft for this highly demanding mission, which ultimately proved an inadequate approach. Indeed, the Air Force only sought to acquire specialized reconnaissance aircraft and imagery satellites after the CIA demonstrated their potential.

In a like manner, France's paramilitary police - the Gendarmerie - developed expeditionary counter-terrorism capabilities that later impelled the armed forces to invest in their own special forces. In this case, the Gendarmerie seized upon the rise in international terrorism in the 1970s to develop counter-terrorism units, the Groupe d'Intervention de la

\footnotetext{
${ }^{22}$ Jeffrey Richelson, The Wizards of Langley: Inside the CIA's Directorate of Science and Technology (Cambridge, Massachusetts: Westview, 2001).
} 
Gendarmerie Nationale (GIGN) and Escadron Parachutiste d'Intervention de la Gendarmerie Nationale (EPIGN). ${ }^{23}$ These forces' specialized skills led political leaders to regard them as a favoured tool for discreet military operations. They, for example, deployed the EPIGN to protect French diplomats in conflict zones ranging from Chad to Lebanon. ${ }^{24}$ More spectacularly, they "lent" the GIGN to Saudi Arabia to help retake Mecca's Grand Mosque from terrorists in 1979 and ordered it to rescue hostages held in caves from the grip of proindependence terrorists in New Caledonia in 1988. Impelled by this threat to their own role in low-intensity military operations, France's Joint General Staff formed a special operations command (the Commandement des Opérations Spéciales) in 1992.

Inter-service and inter-agency competition thus offer two potential mechanisms for obliging reluctant armed services to innovate. These should logically play a significant role with drones since the armed service best positioned to play the leading role - the Air Force is also likely to be the most reticent to do so because of its domination by combat aircraft pilots, who regard drones as a threat to their platform community. In the following pages I will comparatively test the extent to which this innovation was driven by civilian leaders, military bureaucracies, inter-service rivalry and interagency competition. To this end, I adopt an explicitly diachronic approach, examining each factor's role during three distinct periods: 1960-79, 1980-97 and post-1998.

\section{UAVs' Precocious Birth and Death}

Over the course of the 1960s the United States Air Force developed a spectacularly successful drone program. Ultimately, the Air Force procured over 1,000 Model 147 "Lighting Bugs" which conducted a wide-range of missions over North Vietnam, including collecting photographic intelligence, dropping chaff to confuse radars, decoying enemy missiles and even attacking heavily defended ground targets. Precocious to the extreme, drones would not again conduct many of the Lightning Bug missions for decades hence. Political leaders' broad appetite for imagery intelligence to inform their decisions catalyzed the process that ultimately led to the Lighting Bug, but politicians themselves lacked the expertise to determine what platforms to promote. Likewise, although the Air Force managed the Lightning Bug program,

${ }^{23}$ Jean-Marc Tanguy, Missions Extrêmes: Le GIGN et l'EPIGN en operation, 19762017 (Paris: H\&C, 2017). 11-27.

${ }^{24}$ Ibid, 31-79. 
its impetus came from that service's rivalry with the CIA and, to a lesser degree, the Army. It was thus the competition of multiple governmental agencies and armed services to fulfill political leaders' desiderata that generated this first drone revolution.

The Air Force traditionally regarded aerial reconnaissance as its bailiwick and had flown photographic reconnaissance missions (as the Army Air Corps) since the First World War. ${ }^{25}$ Reconnaissance, however, was never a central Air Force priority and the service generally did no more than modify its existing combat aircraft for this mission. During the Cold War, however, such modified bombers (RB-47s and RB-57s) and fighters (RF-101s) were proving inadequate, being recurrently intercepted and shot-down by Communist fighters. The United States, indeed, lost a total of 23 aircraft and 179 aircrew during peacetime reconnaissance missions from 1946 to $1990 .{ }^{26}$ Traditional reconnaissance aircrafts' increasing vulnerability over the course of the 1950s drove civilian policymakers to demand alternative means for obtaining imagery intelligence.

The CIA leapt at the opportunity to fill the resultant gap in national reconnaissance capabilities and worked with Lockheed Aviation's Chief Engineer, Clarence Johnson, to design a specialized reconnaissance aircraft. The resultant aircraft, the U-2, was secretly developed between 1954 and 1956, and could fly higher than any previous aircraft, including 10,000ft higher than the Air Force's highest-flying aircraft. ${ }^{27}$ The U-2's success soon put the CIA in the driver's seat when it came to photographic reconnaissance.

The U-2, however, only guaranteed the CIA preeminence for a short-time. Already in 1957, the Soviet Union began deploying a surface-to-air missile, the SA-2, that would soon put the U-2 at risk. One veteran of the Air Force's drone program described the competition between the CIA and Air Force over aerial reconnaissance as a 'running gun battle' within which 'each organization on a project-by-project basis tried to push the other team out of the picture. ${ }^{28}$ It was, within this context of intense inter-organizational competition that the Air Force embraced drones. Even then, while the Air Force's leadership desperately sought means

${ }^{25}$ Laurence Newcome, Unmanned Aviation: A Brief History of Unmanned Aerial Vehicles (Reston, AIAA, 2004), 35-38.

${ }^{26}$ Ibid, 71.

${ }^{27}$ Curtis Peebles, Shadow Flights: America's Secret Air War Against the Soviet Union (Novato: Presidio, 2000), 96-132.

${ }^{28}$ Steve Miller, The $99^{\text {th }}$ Strategic Reconnaissance Squadron: The Air Force's Story of Unmanned Reconnaissance in the Vietnam War (Everett: Miller Management, 2017), 38. 
for reestablishing their position as a photographic intelligence collector, their use of drones to achieve that end was fortuitous.

Indeed, it was Ryan Aeronautical Company - the producer of the Air Force's Firebee target drone - that began without Air Force encouragement to examine modifying its Firebees for reconnaissance purposes in 1959. Ryan's executives then submitted their unsolicited drone proposal to the Air Force in 1960. At this point, the Air Force accorded such a low priority to reconnaissance as a mission and drones as a platform that they lacked a systems program office (SPO) dedicated to either. ${ }^{29}$ Ryan's proposal therefore might have languished if not for outside events and inter-organizational pressures.

Ryan's drone proposal, however, was evaluated by Air Force leaders in the immediate aftermath of the Soviets shooting down two reconnaissance aircraft; the May 1960 shoot-down of Gary Power's CIA-operated U-2 and the July 1960 destruction of an Air Force RB-47. The notion of an unmanned and therefore expendable reconnaissance platform proved attractive to Air Force leaders after these two incidents, which had killed four American aircrew and led to one's imprisonment in the Soviet Union. The Air Force therefore provided \$200,000 for Ryan to pursue work on its reconnaissance drone project, which soon became known as the Model 147 Lightning Bug. ${ }^{30}$

This financially modest contribution hardly signaled the service's full-fledged commitment to drones. Nevertheless, Air Force commanders felt compelled to continue supporting the project lest rival services and agencies once again wrest leadership of photographic reconnaissance from them. Already, Lockheed was studying building an unmanned version of the U-2 aircraft for the CIA and was also designing a stealthy supersonic reconnaissance aircraft - the A-12 - that could outrun enemy missiles. ${ }^{31}$ The Army Signal Corps, meanwhile, launched its own reconnaissance drone project - the SD-5 - whose capabilities overlapped with those of the Air Force's proposed Lighting Bug. ${ }^{32}$

${ }^{29}$ Miller, 25-26.

${ }^{30}$ Miller, 26.

${ }^{31}$ Ben Rich and Leo Janos, Skunk Works (Boston: Little, Brown and Company, 1994), 262.

${ }^{32}$ CIA, SD-5 Drone Characteristics and Capabilities, 14 February 1962, available at: www.cia.gov/library/readingroom/docs/CIA-RDP71B00822R000100200008-8.pdf (accessed August 2019). 
It was within this context of inter-organizational competition that the Air Force rushed the Lightning Bug into service. The CIA, indeed, appealed to the Executive Branch to take over the Air Force's project in early-October 1962. The prospect of having their project taken from them prompted the Air Force's leadership to deploy prototype Lightning Bug drones to Florida during the Cuban Missile Crisis and dramatically increase the project's funding in 1963. The Air Force, within this context, formed a well-resourced drone unit that same year, equipped with Lightning Bug drones, modified C-130 transport aircraft to launch them and helicopters to recover them mid-air. The Air Force soon flew these drones as part of the Kennedy Administration's effort to destabilize Cuba - Operation Mongoose - hoping that the drones would provoke Cuban surface-to-air missile units into shooting at them and thereby providing a pretext for military retaliation. ${ }^{33}$

These actions, which ensured the Air Force's continued ownership of the project, coincided with the United States' increasing difficulty gathering intelligence over China. It was consequently by providing intelligence on southern China that the Air Force's Lightning Bug attracted the attention of American political leaders. Cloud cover and forests hindered the ability of the United States' spy satellites and high-altitude reconnaissance aircraft to collect photographic intelligence on southern China. Chinese air defenses - both anti-aircraft guns and fighter aircraft - had meanwhile achieved the proficiency needed to intercept a prohibitively large proportion of low-altitude reconnaissance aircraft. Indeed, they had shot down five RF101 and P2V manned reconnaissance aircraft, operated by Taiwan's Air Force in partnership with America's Air Force, between 1961 and 1965. ${ }^{34}$ Flying U-2s at higher altitudes, likewise, was proving suicidal, as demonstrated by the Chinese destruction of three Taiwanese-operated $\mathrm{U}-2 \mathrm{~s}$ in $1964 .^{35}$

The Air Force consequently rushed its Lightning Bug unit to Okinawa in 1964, from whence they flew 15 missions over southern China between August and November. ${ }^{36}$ China's government immediately countered by deploying an elite 'division of ace pilots' to counter the

${ }^{33}$ Miller, 61-70.

${ }^{34}$ Lu Xiaoping, The PLA Air Force (New York: CN Times, 2014), 54-70.

${ }^{35}$ Thomas Ehrhard, Air Force UAV's: The Secret History (Arlington: Mitchell Institute for Airpower Studies, 2010), 9.

${ }^{36}$ NRO, Annual Report on Activities of the National Reconnaissance Program, 31 October 1965, available at: https://www.cia.gov/library/readingroom/docs/CIARDP72R00410R000200010001-5.pdf (accessed August 2019). 
UAVs, yet even this unit found intercepting comparatively small, elusive drones challenging. ${ }^{37}$ Nonetheless, a Chinese pilot eventually shot down a drone on 11 November $1964 .{ }^{38}$ This destruction of a Lightning Bug failed, however, to generate adverse publicity equivalent to that experienced when manned reconnaissance aircraft had been shot down.

Political leaders consequently embraced drones as a politically advantageous means for collecting intelligence and encouraged their development. National Security Adviser Henry Kissinger expressed this view when he opined of the drone operations over southern China, "The $147 \mathrm{H} / \mathrm{T}$ [Lightning Bug] drone is a valuable vehicle for obtaining the type of military tactical intelligence desired. Manned U-2 or SR-71 overflights would be considerably more provocative than drones. Satellite reconnaissance has failed to fill the need [in southern China]." 39 The United States, therefore, continued conducting Lightning Bug missions over South China despite the occasional loss of drones. Altogether, they flew 97 such missions - an average of 19 per year - between 1964 and $1969 .{ }^{40}$

Even more so than China, Ryan Aeronautical's UAVs came fully into their own during the Vietnam War. As America escalated its involvement in that country, it found itself facing formidable North Vietnamese air defenses. Indeed, according to American intelligence, North Vietnam's arsenal of anti-aircraft guns rose meteorically from 943 anti-aircraft guns of all calibers in 1965 to $6000-7000$ large-caliber guns in 1966, all above $20 \mathrm{~mm}$ in caliber. ${ }^{41}$ Likewise, the North Vietnamese began rapidly introducing SA-2 surface-to-air missiles into their arsenal in 1965: the same system that had proven so deadly against the U-2 in other parts of the world.

It was in this increasingly deadly environment that Lightning Bug began to be truly valuable. Although the Lightning Bug project began modestly as an effort to contest the CIA's expanding role in aerial reconnaissance, the Vietnam War highlighted the drone's potential to

${ }^{37} \mathrm{Lu}, 71-72$.

${ }^{38}$ Ibid, 73.

${ }^{39}$ Henry Kissinger, Air Reconnaissance of South China, 9 October 1969, available at: www.cia.gov/library/readingroom/docs/CIA-RDP74J00828R000100200028-9.pdf (accessed August 2019)..

${ }^{40} \mathrm{Lu}, 71$.

${ }^{41}$ Stephen Emerson, Air War Over North Vietnam: Operation Rolling Thunder-19651968 (Barnsley, Pen and Sword, 2018), 49-50. 
the Air Force's combat arms, leading them to promote its continuing development over the war's course. As early as late-1964, Lightning Bugs were conducting reconnaissance sorties out of Bien Hoa against North Vietnamese targets. ${ }^{42}$ As North Vietnamese airspace became increasingly perilous, unmanned aircraft became attractive both to politicians worried about the political embarrassment of captured air crew and to the Air Force's reconnaissance community, which was increasingly conscious of their vulnerability. ${ }^{43}$

The Air Force consequently developed new Lightning Bug variants throughout the war, including models for destroying enemy air defenses, dispensing chaff, collecting signals intelligence and decoying enemy surface-to-air missiles. By the war's end, 1,016 Lightning Bugs flew a total of 3,435 sorties with a mission success rate of 84 per cent. ${ }^{44}$ In achieving this objective, the Air Force created four drone units and fielded 25 different drone variants. While this represented a fraction of total reconnaissance sorties, it still was the first large-scale use of UAVs in warfare.

The United States' withdrawal from the Vietnam War in 1973 posed questions about drones' future. Drones' successes led many to conclude that now was the time to double-down on unmanned aircraft and envisage their increasing use in front-line combat roles. ${ }^{45}$ Drones' combat record in Vietnam, indeed, drove a mushrooming of drone proposals such that 35 distinct Air Force drone programs were underway by 1973, ranging from paper design studies to further modifications of Lightning Bugs. Key amongst these were the BGM-34C project, which aimed to develop an improved Lightning Bug unmanned combat air vehicle (UCAV) capable of delivering a wide-range of weaponry, and the Compass Cope project, which sought to produce a high altitude, long-endurance drone, equivalent to today's Global Hawk. ${ }^{46}$

Despite the Air Force's recent military experience and its range of ongoing drone projects, the inter-organizational competition that had spurred drones' development in the early

${ }^{42}$ William Wagner, Lightning Bugs and Other Reconnaissance Drones (Fallbrook, CA: Armed Forces Journal Books, 1982), 70.

${ }^{43}$ Ibid, 97-98.

${ }^{44}$ Newcome, 86.

${ }^{45}$ Robert Barkan, "The Robot Air Force is About to Take Off," The New Scientist (August 1972), 281.

${ }^{46}$ William Wagner and William Sloan, Fireflies and Other UAVs (Arlington, Texas: Aerofax, 1992), 117-18; and Ehrehard, 32-34. 
1960s no longer existed. The Army was first to withdraw from the field, cancelling its SD-5 in November 1962. Much more consequentially, however, was the CIA's subsequent withdrawal from the airborne photo-intelligence role. The CIA's own drone - code-named the D-21 - had failed and faced cancellation in 1971. This project's objective of building a stealthy supersonic drone, based on A-12/SR-71 technology, proved beyond what contemporary technology could achieve, leading President Richard Nixon to order its cancellation after flying five failed missions over China. ${ }^{47}$ A subsequent Presidential Order, issued in 1976, transferred all of the CIA's aviation assets - manned and unmanned - to the Air Force.

The Air Force, thus, enjoyed a monopoly on drone and aerial photo-reconnaissance capabilities in the Vietnam War's immediate aftermath. With no other agency poised to challenge the Air Force for the mission, that service's leadership could afford to neglect drones. They consequently deactivated three of their four drone units between 1973 and 1976. Then, in 1977, the Air Force cancelled its two premier drone projects - the BGM-34C and Compass Call - when they experienced cost overruns and reliability problems. Although the technical challenges these programs faced were real, they were arguably not more so than those encountered by other sophisticated weapons programs.

However, in the absence of either a pro-drone community within the Air Force or interorganizational competition forcing the Air Force to stay the course, the Air Force's leadership seized upon hiccups in both drones' development to cancel them. Finally, then, in 1979 the Air Force disbanded its last drone unit. As a result, without the original incentive structure that had driven drones' development and with no meaningful competition from other organizations, UAV development was allowed to wither on the vine under a brief Air Force monopoly.

\section{Competition and Drones' Redux}

Since the Air Force's post-Vietnam monopoly on UAVs precipitated the cancellation of drone development projects thereafter, the revitalization of United States military drone capabilities logically occurred once rival services and agencies again invested in unmanned aviation. Indeed, it was first the Navy, followed by the Marine Corps, and then the Army, which acquired reconnaissance drones. These developments rekindled the CIA's interest in drone project as well, leading to the program that ultimately evolved into the Predator drone. Only once it felt that its status as America's premier vector of air power was threatened by other services' drone

\footnotetext{
${ }^{47}$ Rich and Janos, 262-70.
} 
investments did the Air Force follow suit. While inter-organizational competition drove this renaissance in American unmanned aviation, political leaders spurred this process along by setting clear strategic objectives and then encouraging multiple agencies and services to compete to fulfil them.

Even as the Air Force divested itself of its drones in the 1970s, Israel's armed forces built-up a UAV capability that can be seen as the heir to the Air Force's 1960s drone program. The Soviet Union's deployment of new surface-to-air missiles to Egypt and Syria in 1969 led to the destruction of an increasing number of Israeli reconnaissance aircraft. Having heard of the Lightning Bugs' success in Vietnam, Israeli Air Force Chief of Staff Mordechai Hod contacted Ryan Aeronautical. ${ }^{48}$ Ryan, in turn, developed a variant of the Lightning Bug - the Model 124I - to meet Israel's particular requirements, which involved carrying different cameras and launching the drone from the ground, rather than aircraft. ${ }^{49}$ Ryan delivered its first Model 124I to Israel in 1971, which proved invaluable against Arab air defenses during the 1973 Arab-Israeli War. Israeli military commanders appreciated their Lightning Bug derivates to such a degree that they purchased much of the United States Air Force's stockpile when the latter ultimately sold them for scrap. ${ }^{50}$

However, Israel's armed forces had to rely on indigenous firms for their follow-on drone projects since the United States had left this domain. Two Israeli firms, IAI and Tadiran, began developing inexpensive UAVs following the 1973 Arab-Israeli War. One reason Arab air defenses had proven formidable during that war was that their SA-6 missiles were mounted on armored vehicles and regularly shifted locations. Israel's Air Force had trouble tracking and therefore destroying these mobile missiles. The IAI Scout and Tadiran Mastiff UAVs solved this problem after they entered service in 1978 by enabling personnel in Israel to remotely pilot the small UAVs for six-hour missions to scan terrain for mobile missiles. The UAVs' cameras instantaneously transmitted images back to base, enabling planners to plan strikes against fleeting targets. ${ }^{51}$

\footnotetext{
${ }^{48}$ Wagner and Sloan, 50.

${ }^{49}$ Ibid, 51-54.

${ }^{50}$ Ibid, 63-64.

${ }^{51}$ Eliezer Cohen, Israel's Best Defense: The First Full Story of the Israeli Air Force
} (New York: Orion, 1993), 429. 
Although Israel's Mastiffs and Scouts were less costly and sophisticated than the American-made Lighting Bugs - featuring propellers rather than jet engines - they provided the cost-effective edge that Israel needed when it next went to war. Israeli firms clandestinely developed these technologies, as well as new electronic jamming pods, in under five years. Israel put these SAM-suppression adaptations to the test during the 1982 Lebanon War. Syrian President al-Asad deployed 19 SA-6 missile batteries - more SA-6s than Syria had possessed in 1973 - to Lebanon's Beka'a Valley in April 1981 to deter Israel from intervening. ${ }^{52}$

Israel's UAVs, however, emboldened Defense Minister Ariel Sharon and Chief-ofStaff Raphael Eiten to argue in 1982 that Israel could win a swift victory, at little cost, by first destroying Syria's air defenses and then pummeling hostile ground forces. Israeli UAVs subsequently ferreted out Syrian SAM batteries' positions in the months before Israel's invasion. Israel's Air Force then attacked on 9 June, destroying 17 of Syria's 19 SAM batteries, while suffering no losses of their own. This offensive eradicated Syria's SAM network in a single stroke, rendering Syrian ground forces defenseless against Israeli air strikes. ${ }^{53}$

Israel's facile success with UAVs spurred emulation by all the United States' armed services, with the notable exception of the Air Force. The Navy led the way in embracing Israeli-style drones after having failed in its attempts at "gunboat diplomacy" in Lebanon in 1983. After America's government had intervened in Lebanon, the Navy sought to use its large warships - battleships and aircraft carriers - to coerce the Syrian Army and various Lebanese militias into cooperating. At a technical level, however, American sea power proved impotent. Battleship cannons could theoretically bombard targets at a distance of $39 \mathrm{~km}$, yet battleships had no means for observing where their shells landed at that distance, which meant that they often missed their objective. When the Navy used jets to attack Syrian artillery, the result was even worse, with the Syrians shooting down three American aircraft in a single day. ${ }^{54}$

The contrast between the Israelis' facile destruction of Syria's air defenses and the Navy's humiliation at those same Syrians' hands drove Navy Secretary John Lehman and Marine Corps General Al Gray to successfully lobby in 1984 for the purchase of small numbers

52 Yair Evron, War and Intervention in Lebanon: The Israeli-Syrian Dialogue (Abingdon: Routledge, 1987), 60-104. 11.

${ }^{53}$ David Clary, The Bekaa Valley-A Case Study (Maxwell: Air University, 1988), 924, 1984).

${ }^{54}$ Richard Halloran, "US Buys Israeli Pilotless Planes." The New York Times (May 
of Mastiff UAVs for testing. Experimentation with these Mastiffs led the Navy and Marine Corps to commission Israel's Tadiran firm to develop an improved Mastiff - the RQ-2 Pioneer - for them. ${ }^{55}$ Lehman - a politically appointed civilian - proved the most enthusiastic advocate of the Navy's drone program, encouraging the Navy's surface warfare community's interest in drones and combating naval aviators' opposition to them. Tadiran and its American jointventure partner, AAI Corporation, delivered the first eight Pioneers to the Navy in 1986, whence they were deployed aboard battleships. The Marine Corps subsequently received Pioneers in 1987 and the Army acquired them beginning in $1990 .{ }^{56}$

Although the Navy, Marine and Army inventories of Pioneers were comparatively modest, all three services employed their UAVs for the 1991 Gulf War. During that conflict, Pioneer UAVs scouted for the United States' battleships, which spectacularly bombarded Kuwait's coast with their 16-inch guns, and flew reconnaissance missions in support for advancing Marine and Army units. Altogether, the Marines' Pioneers flew 323 missions, the Navy's flew 83 and the Army's 46. ${ }^{57}$ Beyond their military utility, UAVs captured the public imagination, which witnessed their being launched from battleships live on television. News reports, further, highlighted an unprecedented incident, when a group of Iraqi soldiers attempted to surrender to a Pioneer; marking the first known instance of human soldiers capitulating to an unmanned aircraft. ${ }^{58}$

Post-war evaluations emphasized how valuable UAVs were. One Marine Corps intelligence officer, for example, told Congressional staffers that his division could have used three times as many drones as they possessed. ${ }^{59}$ General Walter Boomer, commander of Marine forces during the Gulf War, further praised the Pioneer as that War's 'single most valuable

${ }^{55}$ Bill Yenne, Attack of the Drones: A History of Unmanned Aerial Combat (Saint Paul: Zenith, 2004), 37.

${ }^{56}$ Ibid, 53.

${ }^{57}$ Ibid, 54.

${ }^{58}$ Stephen Carr and John Keane, "A Brief History of Early Unmanned Aircraft." Johns Hopkins APL Technical Digest 32/3 (2013), 569.

59 "Intelligence Successes and Failures in Operations Desert Shield/Storm.” Report of the Oversight and Investigations Subcommittee, Committee on Armed Services (U.S. House of Representatives, 1993), 9. 
intelligence collector. ${ }^{60}$ The Pioneers' success in the Gulf War drove the Army to seek a more robust reconnaissance UAV of its own. The resultant UAV-SR (Short Range) competition of 1991-1993, in turn, led to the Army's selection of a drone - the Hunter - designed by Israel Aerospace Industries. ${ }^{61}$ The Army purchased 56 Hunters, in turn, which began entering service in 1995.

Even as the Navy, Marines and Army cultivated modest drone capabilities through the purchase of modified Israeli systems, other United States government agencies promoted drones as well. The Defense Advanced Research Projects Agency (DARPA), a Defense Department agency dedicated to cultivating advanced technologies for eventual use by the armed forces, sponsored a succession of reconnaissance drone projects in the 1980s and 1990s. DARPA funded the development of the massive Condor UAV by the Boeing Corporation in the 1980s. This large $(9,000 \mathrm{~kg})$ high-altitude $(67,000 \mathrm{ft})$ drone was designed to offer an inexpensive alternative to spy satellites. ${ }^{62}$ DARPA later launched its advanced airborne reconnaissance program in 1993, which funded Lockheed Martin's development of the stealthy Darkstar drone and Boeing's high altitude Global Hawk. ${ }^{63}$ Despite DARPA's efforts to fund advanced drones, the armed services long hesitated to adopt DARPA's programs as their own and fund their development into deployable military systems.

One of the DARPA projects, however, would ultimately evolve into the Predator project, which became the single most momentous drone project of the period. In 1984, DARPA contracted Abraham Karem, an Israeli engineer who had emigrated to the United States, with developing an experimental UAV called Amber. Amber, in principle, would be a propeller-driven reconnaissance UAV that could also attack targets of opportunity by jettisoning its wings and arming a warhead in its nose. ${ }^{64}$ The $\$ 5$ million DARPA grant, however, proved insufficient to fund Amber's development or support Karem's start-up company. Karem, consequently, sought to develop a less sophisticated observation drone, without Amber's kamikaze capability, to sell to foreign clients. This drone, dubbed the Gnat-
${ }^{60}$ Yenne, 54.
${ }^{61}$ Ibid, 49-51.
${ }^{62}$ Ibid, 47-49.
${ }^{63}$ Ibid, 71-76.
${ }^{64}$ Christopher Fuller, See it, Shoot it: The Secret History of the CIA's Lethal Drone Program (New Haven: Yale UP, 2017), 105. 
750, failed to save Karem's firm, which was bought by Hughes Aviation, and then was sold again to General Atomics.

The wars that broke out in the former Yugoslavia in the early 1990s, however, won Karem's Gnat-750 attention from the CIA. Ubiquitous cloud cover and mountainous terrain meant that the United States' surveillance satellites frequently failed to furnish adequate intelligence on developments in the Balkans. Serbian air defenses, meanwhile, dissuaded the United States from flying low-level manned reconnaissance missions. President Bill Clinton personally favored the United States' playing a larger role in resolving these conflicts and his cabinet therefore prioritized obtaining high-quality photographic intelligence in the Balkans. CIA Director James Woolsey, within this context, directed his agency's technical services to partner with General Atomics in 1993 to expeditiously deploy Gnat-750s for reconnaissance. By February 1994, a mixed team of CIA personnel and General Atomics employees operated Gnat-750s over Bosnia out of a base in Albania. ${ }^{65}$

Faced-paced testing of the Gnat-750, however, revealed significant scope for improving the UAV. DARPA, consequently, founded the Gnat-750's redesign, with a larger airframe and a satellite communications link, into the UAV now known as the Predator. Approved under the Defense Department's Advanced Concept Technology Demonstration (ACTD) rules, which allowed for a faster acquisition strategy, the Predator was fielded with remarkable speed. ${ }^{66}$ After an initial demonstration in 1994, the aircraft was flying reconnaissance missions in July 1995. ${ }^{67}$ Although limited by adverse weather, the Predator proved superior to manned aircraft when it came to gathering intelligence over large areas for extended periods of time.

As the Predator program progressed, however, a traditional military service - the Army - began to covet it. The Army had long toyed with unmanned aviation as a means of compensating for what it perceived to be the low priority that the Air Force attached to supporting ground forces. Congress, however, cancelled the Army's principle UAV program to date - the Aquila drone - in 1987, after eight years of development and amidst claims that

${ }^{65}$ Ibid, 112-13.

${ }^{66}$ Christopher Jones, Unmanned Aerial Vehicles: An Assessment of Historical Operations and Future Possibilities. (Montgomery: Air Command and Staff College Research Paper, 1997), 43.

${ }^{67}$ Ibid, 32. 
the program had been poorly managed. ${ }^{68}$ The Aquila's objective of providing both an inexpensive reconnaissance platform and a system capable of directing laser-guided artillery shells proved more than contemporary technology could accomplish.

After the Aquila's cancellation, the Army followed the Navy's lead in purchasing Pioneers and then purchased Israeli-designed Hunters as well. The Army's leadership, therefore, naturally proposed the services of their Military Intelligence Battalion (Low Intensity) for testing the Predator. ${ }^{69}$ It was thus under the Army that the Predator made its operational debut in 1995 - first in the multi-national Roving Sands military exercise and then in providing intelligence over Bosnia. ${ }^{70}$

It was only at this stage, once the Predator's viability had been proven over the Balkans and a rival military service had expressed interest in it, that the Air Force sought to appropriate the program. The Predator's development until this point benefitted from support by DARPA, the CIA and then the Army. The Navy and Marine Corps, meanwhile, demonstrated their curiosity about the system by sending one pilot apiece to observe the system's debut in the Balkans. The Air Force, indeed, was conspicuous for being the last armed service to express interest in the Predator program.

At the point when the system was poised to enter full-scale production, however, the specter of a rival organization developing a sizeable airborne reconnaissance capability drove the Air Force's leadership to seek to appropriate the project. Air Force Chief of Staff, General Ronald Fogleman, consequently ordered the creation of the $11^{\text {th }}$ Reconnaissance Squadron in July 1995: the first operational Air Force UAV squadron since the last one's disbandment in 1979. ${ }^{71}$ Fogelman, however, recognized that the Air Force needed to appear even more bullish on drones or else other services and agencies would encroach in this domain on the Air Force's status as America's premier employer of airborne systems.

${ }^{68}$ Government Accounting Office, Aquila Remotely Piloted Vehicle Recent Developments and Alternatives (Washington D.C.: USGPO, 1986).

${ }^{69}$ Richard Whittle, Predator: The Secret Origins of the Drone Revolution (New York: Henry Holt, 2014), 91.

${ }^{70}$ Ibid, 99-101.

${ }^{71}$ Thomas Ehrhard, Unmanned Aerial Vehicles in the United States Armed Services: A Comparative Study of Weapon System Innovation. (PhD Thesis, Johns Hopkins University, 2000), 541. 
He therefore overruled the $11^{\text {th }}$ Reconnaissance Squadron's first commander by advocating for the Predator's rapid acquisition even after the latter had cautioned that the Predator was still too unreliable. ${ }^{72} \mathrm{He}$ also articulated an ambitious Air Force strategy for UAVs, wherein the Predator would provide an interim capability until the Air Force could procure the stealthy DarkStar and high altitude Global Hawk, whose development DARPA had initiated. To this end, Fogelman established an Air Force Systems Program Office (SPO) in late-1995 tasked with taking over these two UAV development programs from DARPA. ${ }^{73}$ The Air Force's leadership subsequently argued to political leaders that they should assign the Air Force ownership of the burgeoning Predator program and, more broadly, recognize it as the United States' lead service for drones.

Fogelman's politically savvy gambit succeeded beyond his own expectations in 1996 and 1997. Defense Secretary William Perry decided in April 1996 to "give" the Air Force the Predator program, permitting the Army to continue operating the drones over the Balkans only until the Air Force could train its own personnel to take over. ${ }^{74}$ The House Intelligence Committee, meanwhile, ruled in 1997 that the CIA should hand over all of its functions related to the Predator to the Air Force. ${ }^{75}$ DARPA, meanwhile, prepared to transfer responsibility for the DarkStar and Global Hawk to the Air Force in the late-1990s. ${ }^{76}$

The Air Force thus appeared poised in the late-1990s to reestablish both a robust UAV capability and the monopoly on drones that it had enjoyed in the 1970s. This development came on the heels of a decade of heady drone development that had been fueled by interorganizational competition. Although political leaders promoted this process at critical junctures, such as when Naval Secretary Lehman pushed to acquire Israeli drones or when President Clinton prioritized obtaining intelligence in the Balkans, it was the competition between the Navy, Marines, Army, DARPA and the CIA to meeting political leaders' desiderata that generated innovation. The Air Force, however, long remained the most reticent service when it came to UAVs. Indeed, only the real prospect of two rival organizations - the

\section{${ }^{72}$ Ibid, 543.}

${ }^{73}$ Testimony of Charles Heber (DARPA), Senate Armed Services Committee, 9 April 1997.

\footnotetext{
${ }^{74}$ Whittle, 111.

${ }^{75}$ Fuller, 114.

${ }^{76}$ Testimony of Charles Heber.
} 
Army and CIA - developing the Predator into a significant airborne asset finally drove the Air Force to embrace drones and seek leadership over their subsequent development.

\section{Consolidating the Innovation}

Questions might legitimately have been asked as to how the United States' drone projects would evolve after the febrile period of drone development in the 1980s and 1990s. The Air Force, under Fogleman's command, had belatedly, yet enthusiastically embraced drones. Espousing a more ambitious vision of drones than rival organizations, the Air Force had provisionally won control over the United States' premier drone projects - Predator, Global Hawk and DarkStar - in 1996-97. Would the Air Force, however, use its newly reestablished preeminence to aggressively develop drones or, rather, scale-back its drone efforts as Air Force leaders had done in the late-1970s? On this occasion, inter-organizational rivalry obliged the Air Force to continue investing in UAVs. Civilian policymakers and rival organizations alike contested the Air Force's pretensions towards a monopoly on drones and thereby obliged it to continue pursuing the innovation.

No sooner had the Air Force won control of the Predator program in 1996 than the Army began manifesting its discontent with the arrangement. Air Force pilots assigned to Predator indeed reportedly showed contempt for the unmanned vehicle during the handover meeting between the Air Force officers who were scheduled to take over Predator and the Army officers who had been operating it. ${ }^{77}$ This led the Predator's Program Officer to question, 'Maybe Fogleman really wanted Predator, but maybe Air Force leaders just wanted to keep another service from having it. ${ }^{78}$ Army units engaged in peacekeeping in Bosnia then complained in 1997 that the Air Force's Predators were not adequately supporting them. ${ }^{79}$

Claims that the Air Force was misusing Predator prompted Air Force leaders to redouble their commitment to it. Fogleman, to this end, selected a rising star within the Air Force, Colonel James Clark, to take over the $11^{\text {th }}$ Reconnaissance Squadron in $1997 .^{80}$ Improving Predator subsequently became an Air Force priority and the service endeavored to prove its competence. During the 1999 Kosovo War, Air Force Predators demonstrated a

\footnotetext{
${ }^{77}$ Whittle, 113.

${ }^{78}$ Ibid, 112.

${ }^{79}$ Ibid, 113.

${ }^{80}$ Ibid.
} 
greatly improved ability to broadcast images directly to NATO and American headquarters by satellite. Air Force, technicians, meanwhile, operated their Predators aggressively; collecting imagery below the Balkans' cloud cover that other reconnaissance assets - satellites and manned aircraft - could not.

Summarizing the Predators' accomplishments over Kosovo, RAND Corporation analyst Benjamin Lambeth enthused that,

[F]or the first time in American combat experience, UAVs offered commanders and planners the frequent advantage of real-time video imagery without any accompanying danger of aircrew losses.... Several UAVs were lost when commanders requested closer looks, forcing the drones to descend into the lethal envelopes of Serb AAA and man-portable air defense systems (MANPADS). These losses did not evoke great concern, however, since the UAVs were intentionally sent out on missions that were known ahead of time to be especially risky. ${ }^{81}$

Operated in this way, the Air Force lost four Predators to Serbian air defenses; a figure which was high compared to the losses of NATO's manned aircraft, of which two were lost during war, yet still considered acceptable. ${ }^{82}$

The Air Force also frenetically developed a laser designator to enable its Predators to guide laser-guided bombs dropped by aircraft flying above the cloud cover onto targets that the aircraft themselves could not see. So expeditiously was this laser-equipped Predator developed that a prototype conducted a mission over Kosovo on the war's penultimate day. The Air Force's commander during the Kosovo War, General John Jumper, soon advocated for expanding the Predator program. Jumper's frustration that Predators frequently spotted enemy targets, yet no friendly aircraft was available to strike them, led him to champion arming Predators in March 2000. ${ }^{83}$

From his new position as head of Air Combat Command, Jumper pushed Air Force engineers to weaponize Predator. These latter, in turn, identified the Hellfire anti-tank missile as a suitable munition and began modifying both the drone and the missile for use together. Anticipating the Air Force's arming of Predators, General Atomics began to develop a technology demonstrator of a scaled-up Predator in 1999 - later known as Reaper - designed

${ }^{81}$ Benjamin Lambeth, NATO's Air War for Kosovo: A Strategic and Operational Assessment (Santa Monica: RAND ), 94.

${ }^{82}$ Ibid, 97.

${ }^{83}$ Fuller, 116. 
specifically to carry larger payloads and more weaponry. ${ }^{84}$ That same year of 1999 , meanwhile, the Air Force partnered with DARPA and NASA to sponsor a stealthy, sophisticated Unmanned Combat Aerial Vehicle (UCAV) project. This project aimed to explore the next generation of armed drones by contracting with Boeing to develop the X-45. ${ }^{85}$

Other organizations, however, took umbrage at the Air Force's pretensions to a monopoly on drones. The Navy's leadership, for its part, responded by seeking to establish a commanding position over the next generation of UAV technology and thereby preclude the Air Force from perpetuating the stranglehold it had established over the Predator project. To this end, they contracted Lockheed Martin in 1997 to analyze the prospects for a stealthy Unmanned Combat Aerial Vehicle (UCAV), dubbed the Uninhabited Naval Strike Aircraft (UNSA). ${ }^{86}$ The Navy subsequently partnered with DARPA in 2000 to sponsor a stealthy UCAV project equivalent to the $\mathrm{X}-45$. This project, termed the $\mathrm{X}-47$, aimed to test technologies for operating sophisticated UCAVs from aircraft carriers. ${ }^{87}$

The Navy's rivalry with the Air Force over the next generation of drones coincided with CIA's efforts to break the Air Force's monopoly over Predator. Agents at the CIA's Counterterrorism Center sought means for collecting intelligence on Osama bin Laden and his compatriots in Afghanistan after American cruise missiles had failed to inflict meaningful damage on al-Qaeda in 1998. Predator's effectiveness in Kosovo in 1999 prompted the Counterterrorism Center's leaders to lobby for the use of Predator over Afghanistan in 2000 to pinpoint bin Laden's whereabouts, a mission that the drone successfully accomplished in September $2000 .^{88}$ The unarmed Predator's accomplishment at collecting imagery of bin Laden, however, prompted some to argue that the CIA needed access to armed Predators, with which they could assassinate figures such as bin Laden if the opportunity arose. The debate about whether the CIA should acquire armed Predators thus raged throughout early-2001, with

${ }^{84}$ Peter Merlin, Ikhana: Unmanned Aircraft System Western States Fire Missions (Washington D.C.: NASA, 2009), 4-5. $19-21$.

${ }^{85}$ Hugh Harkins, X-45: Uninhabited Combat Air Vehicle (Glasgow: Centurion, 2013),

${ }^{86}$ Ibid, 10.

${ }^{87}$ Ibid, 75-83.

${ }^{88}$ Whittle, 148-57. 
CIA Director George Tennet opposing the move and National Security Council's Counterterrorism Coordinator, Richard Clarke, and the CIA's Counterterrorism Center favoring it. ${ }^{89}$

The Air Force's preeminence in the domain of drones was thus already a contested reality when al Qaeda operatives attacked the United States on 11 September 2001. These attacks and the United States' subsequent invasions of Iraq and Afghanistan, however, transformed the inter-organizational struggle over UAVs by dramatically increasing the resources involved. For example, whereas the United States armed forces possessed a total of 82 drones in 2001 , they would own approximately 8,000 by $2010 .{ }^{90}$ Civilian policymakers were particularly bullish on drones in the so-called "War on Terror" because of the reduced political costs for operating them over neutral countries.

Political leaders consequently pushed the armed forces to prioritize these systems. The Senate Armed Services Committee in 2001 even set as a goal that one-third of the military's deep strike aircraft consist of unmanned UCAVs by 2010. ${ }^{91}$ The Air Force's leadership, within this context, showed much less enthusiasm for drone than their political leaders. For example, in fiscal year 2003, the Air Force requested a mere \$23 million for seven new Predators only to have Congress instead appropriate $\$ 131$ million for the purchase twenty-nine. ${ }^{92}$ Even more worryingly from drone proponents' perspective, the Air Force failed to promote any drone programs as follow-ons to the Predator and Global Hawk projects that it had taken over in the late-1990s. Air Force leaders, indeed, cancelled the futuristic X-45 project, which had evolved into the J-UCAS program, in 2006 after escalating the performance requirements that it insisted the UCAV meet. ${ }^{93}$ They also resisted reallocating money from their U-2 program to accelerate Global Hawk's development. ${ }^{94}$

Dissatisfaction with the Air Force's approach led political leaders to increase their support for rival organizations. The CIA was first to benefit from this dynamic. President

${ }^{89}$ Ibid, 182-231.

${ }^{90}$ Ibid, 299.

${ }^{91}$ Elizabeth Bone and Christopher Bolkcom, Unmanned Aerial Vehicles: Background and Issues for Congress (Washington D.C.: Congressional Research Service, 2003), 8.

92 GAO. Improved Strategic Planning Can Enhance DOD's Unmanned Aerial Vehicle Efforts. (Washington D.C., USGPO, 2004), 2.

${ }^{93}$ Harkins, 79-83.

${ }^{94}$ Bone and Bolkcom, 35. 
George W. Bush expeditiously approved the CIA's acquiring an extensive drone fleet and using those drones for assassinations both over countries where the United States was officially conducting combat operations as well as others where it was not. ${ }^{95}$ On 8 October 2001 the CIA consequently conducted its first drone strike - a failed attempt on Afghan leader Mullah Omar - which was followed in mid-November by the successful strike on al Qaeda's third highestranking official, Mohammed Atef. ${ }^{96}$ The CIA's involvement with drones subsequently grew such that the Agency, by 2014, owned 80 Predators. ${ }^{97}$

Other armed services also benefitted from civilian leaders' dissatisfaction with the Air Force. The Army, for example, obtained Congressional approval for producing a new tactical UAV, the RQ-7 Shadow, in 2003 and a smaller man-portable UAV, the RQ-11 Raven, in 2005..$^{98}$ More ambitiously, the Army invited defense firms to submit proposals in 2002 for a larger Extended-Range Multi-Purpose UAV for surveillance purposes. Army leaders then selected a drone, named Warrior and then Grey Eagle, which was in actuality a slightly larger version of Predator. The Navy, meanwhile, launched an ambitious Broad Area Maritime Surveillance (BAMS) requirement in 2003, which envisioned the use of sophisticated, large UAVs to monitor the world's oceans. The first phase of BAMS envisaged the Navy acquiring Global Hawk UAVs before then developing a more specialized platform. ${ }^{99}$ With the Navy acquiring Global Hawks, and the Army and CIA Predators, the Air Force's primacy within the drone arena was fading fast.

Restoring the Air Force's monopoly over the use of UAVs became one of the service's priorities in 2006. To do this, the Air Force's leadership argued that their service should become the executive agency of all UAVs flying above $3500 \mathrm{ft}$ and that the next wave of long endurance

95 Jane Mayer, “The Predator War: What are the risks od the C.I.A.'s covert drone program?” The New Yorker (26 October 2009).

${ }^{96}$ Whittle, 247-93.

97 “Just How Many Predator Drones Does the CIA Have?" War Is Boring (15 October 2014).

${ }^{98}$ GAO, 8; and Bone and Bolkcom, 30-31.

${ }^{99}$ Bone and Bolkcom, 41-43. 
UAVs should be developed and managed under their aegis. ${ }^{100}$ The Air Force's leadership argued to this effect that theirs' was the most experienced service at handling UAVs and also possessed superior expertise in the related domains of cyberspace and satellite communications. ${ }^{101}$ Understandably, the Navy's and Army's representatives bristled at the Air Force's attempt to claim ownership over their programs, igniting a public debate over who should control UAVs. ${ }^{102}$

Defense Secretary Robert Gates intervened at this point to decisively thwart the Air Force's bid for control. Gates, indeed, provocatively criticized the Air Force's pilot-centric culture and encouraged them to follow the Army's example in adapting to new innovations in a 2008 speech at Maxwell Air Force Base. ${ }^{103} \mathrm{He}$ also announced the creation of a joint UAV task force that would hasten the fielding of UAVs for the Iraq and Afghanistan wars. ${ }^{104}$ Gates's advocacy for the Army extended to supporting them in developing a self-sufficient surveillance unit known as Task Force ODIN, a move that was in direct conflict with the Air Force's monopolization strategy. ${ }^{105}$ Finally, Gates's most dramatic move against the Air Force came in his simultaneous firing of both the Air Force's Secretary and Chief of Staff in June 2008. While that move came as a response to a range of scandals, it also symbolized Gates's adversarial relationship with the Air Force's leadership. ${ }^{106}$

${ }^{100}$ Sanford Weiner, "Evolution in the Post-Cold War Air Force: Technology, Doctrine and Bureaucratic Politics," in Harvey Sapolsky et al., US Military Innovation Since the Cold War: Creation Without Destruction (Abingdon: Routledge, 2009), 113.

${ }^{101}$ House Armed Services Committee, Hearing on Budget Request on Unmanned Aerial Vehicles (UAV) And Intelligence, Surveillance, and Reconaissance (ISR) Capabilities (April 19, 2007), 25.

102 Ibid, 32-35; and Demetri Sevastopulo, "US Military in Dogfight Over Drones." The Financial Times (August 19, 2007)

${ }^{103}$ Robert Gates, Secretary Gates Remarks at Maxwell-Gunter Air Force Base, Montgomery Alabama (Transcript: US Department of Defense, April 21, 2008).

${ }^{104}$ Donna. Miles, "Gates Forms Task Force to Promote Intelligence, Surveillance for Warfighters.” American Forces Press Service (April 21, 2008).

105 Thom Shanker, "At Odds with Air Force, Army Adds its Own Aviation Unit." The New York Times (June 22, 2008).

106 Julian Barnes and Peter Spiegel, “Air Force’s Top Leaders are Ousted.” Los Angeles Times (June 06, 2008). 
With no single service enjoying a monopoly, they all have continued competing for the roles and missions associated with drones. For example, although neither the Air Force nor the Navy have procured a stealthy UCAV capable of substituting for manned combat aircraft, both services have advanced a succession of related projects. The Navy, to this end, is developing a stealthy flying wing - the MQ-25 - to refuel its carrier-based combat aircraft mid-flight. ${ }^{107}$ The Air Force, for its part, is developing both so-called "loyal wingman" drones to support manned combat aircraft flying alongside and long-range bomber drones. ${ }^{108}$ The Army and CIA, meanwhile, are innovating in how they employ drones. Although the CIA's drone campaign remains cloaked in secrecy, the Agency is reportedly employing new techniques to combine and analyze data from multiple sources to identify high-value insurgents to strike with their drones. The Army, for its part, is seeking to equip each of its active-duty divisions with a company of Hellfire-armed Grey Eagles.

\section{Conclusion}

Inter-organizational rivalry has been critical to driving the United States' development of drones. All four of America's armed services have played roles in this process, as did the CIA and DARPA. Indeed, drone development was rapid whenever two or more organizations competed to field operational UAVs. Drone development was contrarily sluggish to nonexistent whenever a single organization exercised a monopoly. This finding that interorganizational competition drove drone innovation in the United States does not suggest that civilian leaders and military bureaucracies played negligible roles. Rather, both fulfilled necessary functions, but were in themselves insufficient to generate innovation in the absence of inter-organizational competition.

The organization that objectively played the principle role in introducing sophisticated drones into service was, however, the Air Force. The Lightning Bug, Predator, Reaper and Global Hawk all, within this context, achieved fully operational status under the Air Force's aegis. The apparent paradox of inter-organizational competition driving innovation, yet the Air Force's playing role in the fielding of more sophisticated drones, demonstrates how

${ }^{107}$ Sam LaGrone, "U.S. Carriers Need New Lethal Unmanned Aircraft, New Fighter to Stay Relevant," USNI News (March 5, 2019).

108 Jason Sherman, "Pentagon Sets Plan for New Bomber," Inside the Air Force (January 13, 2006); and Beth Stevenson, "'Loyal Wingman' Part of the Future of Air Combat," Defense News (June 13, 2019). 
competition as a mechanism provides an impetus for innovation. As the only military service dedicated to the pursuit and employment of air power, no other service can equal the Air Force in terms of the size of its procurement bureaucracy dedicated to aircraft or the depth of its relationship with aerospace firms. One would therefore expect the Air Force under ceteris paribus conditions to be the most competent service when it comes to managing drone projects. The Air Force's domination by pilots of manned combat aircraft, however, also aggravated the service's biases against drones. In many respects, these motivated biases are subtle, rather than explicit. Thus, rather than outright seeking to cancel drone projects to protect piloted aircraft, Air Force leaders have rather perceived drones' shortcomings more acutely than those of manned aircraft. Consequently, when resources are finite and projects' futures' uncertain, Air Force leaders tend to cancel unmanned systems rather than equally problematic manned aircraft. The Congressional Research Service characterized the Air Force's outlook as being one of relishing drones as a complementary asset to manned aircraft, but rejecting them as a possible substitute for them. ${ }^{109}$

The Air Force's motivated biases have always had considerable scope for expression. Such is the case because the trade offs between drones and manned aircraft are often ambiguous. Unmanned aircraft are often touted for their lower acquisition costs and ability to patrol for extended periods over battlefields. Manned aircraft, however, are often more capable and have lower accident rates. Unmanned aircraft, moreover, often require more significant ground infrastructures, which challenge facile calculations about cost-effectiveness. When future systems are being considered, the issue as to whether a manned or unmanned option will prove superior often hinges on the fate of as yet immature technologies, such as artificial intelligence or data links. Indeed, drones' one unambiguous advantage - the lower political costs of their use because of the absence of pilots who can be captured or killed - is of such a nature that Air Force officers are likely to give it short-shrift in peacetime.

Given this persistent ambiguity about unmanned and manned aircraft's relative merits, is it any wonder that an Air Force led by combat aircraft pilots would systematically opt for manned solutions? Inter-organizational competition alone can drive the Air Force to promote unmanned solutions under such circumstances. Indeed, the prospect of another service or agency encroaching on the Air Force's position as the United States' principle operator of military aircraft through the successful fielding of UAVs can exercise a powerful influence

${ }^{109}$ Bone and Bolkcom, 8. 
over the Air Force's leadership. It was thus the CIA's competition as a provider of aerial reconnaissance that prompted the Air Force to embrace the Lightning Bug and the prospect of the Army acquiring Predator that led the Air Force to seek control of the project.

Competition between rival organizations was thus central to drone innovations and innovation consequently ceased whenever the Air Force exercised a monopoly. It was civilian leaders' actions, however, that determined the incidence of such "creative" competition. Innovation, within this context, occurred whenever political leaders set forth clear operational objectives and then encouraged multiple organizations to compete to fulfill them. The priority the Kennedy and Johnson administrations attached to collecting intelligence over China and President Clinton's demand for imagery in Bosnia constitute two cases in point of political leaders indirectly promoting drone innovations by setting strategic goals and then selecting amongst the proposals to achieve them. At times, such as Navy Secretary Lehman's advocacy of Israeli drones or the Senate's setting of an ambitious "headline goal" for UCAV procurement, civilians tried to promote drones more proactively.

On balance, however, the indirect approach of encouraging inter-organizational competition proved more fruitful to innovation than the direct one of prodding armed services to invest in drones. Civilian policymakers eventually recognized this reality and they consequently exploited inter-organizational competition to oblige armed services to provide them with capabilities they consider essential. The Congressional Research Service articulated this growing consciousness on political leaders' part by observing that, "if UAS [Unmanned Aerial System] efforts are too centralized [by the Air Force]... competition and innovation may be repressed."110

This finding - that inter-organizational competition provided the primary impetus for drones' development - is robust even considering drones' rapid development in wartime. At first glance, American drones' astonishing progress during the Vietnam War and, later, during the so-called War on Terror suggests that military organizations develop drones slowly in peacetime, yet rapidly in wartime. In both cases, small peacetime Air Force inventories that included modest numbers of specialized reconnaissance drones burgeoned under the pressure of urgent operational requirements into large diversified drone forces. Nonetheless, this rapid wartime expansion of Air Force drone capabilities was only possible due to the interorganizational competitions that preceded the outbreak of war. Indeed, the drone models that

110 Jeramiah Gertler, U.S. Unmanned Aerial Systems (Washington D.C.: Congressional Research Service, 2012), 10. 
became emblematic of the two conflicts - the Lightning Bug in Vietnam and the Predator during the War on Terror - were both quintessential products of inter-organizational competition and were already in service when those conflicts began. In other words, while wartime exigencies fueled dramatic growth in unmanned aviation, this was only possible because competition in peacetime generated the systems that made that growth possible.

While drones - the innovation featured in this study - may appear at first glance to be a technology whose development is particularly prone to inter-organizational competition since multiple agencies and organizations possess aviation assets, there are strong reasons for anticipating that a large and growing range of national security capabilities may be subject to this form of innovation. As mentioned in the introduction, paramilitary police forces - ranging from France's gendarmerie to China's People's Armed Police - compete with conventional ground forces for missions such as peacekeeping, counterinsurgency and counter-terrorism. Coast guards and maritime militias, meanwhile, vie with navies for roles in upholding states' maritime boundary claims and patrolling their exclusive economic zones (EEZs). Emerging technologies, such as cyberwar and artificial intelligence, finally, offer new horizons for interorganizational competition since responsibility for these domains in any give state is generally diffuse across multiple military services and intelligence agencies.

In sum, inter-organizational competition has already been critical to drones' emergence as a major military innovation and is likely to play an even larger role in the future given the evolving technologies and security challenges that states face. 